\title{
Tobacco Seeds By-Product as Protein Source for Piglets
}

\author{
Luciana Rossi $^{{ }^{*}}$, Eleonora Fusi ${ }^{1}$, Gianluca Baldi ${ }^{1}$, Corrado Fogher ${ }^{2}$, \\ Federica Cheli ${ }^{1}$, Antonella Baldi ${ }^{1}$, Vittorio Dell'Orto ${ }^{1}$ \\ ${ }^{1}$ Department of Health, Animal Science and Food Safety, Università degli Studi di Milano, Milan, Italy \\ ${ }^{2}$ Institute of Agronomy, Genetics and Field Crops, Catholic University, Piacenza, Italy \\ Email: *luciana.rossi@unimi.it
}

Received December 28, 2012; revised February 1, 2013; accepted March 2, 2013

\begin{abstract}
Tobacco seed cake is a by-product with interesting characteristics for animal nutrition, due to its high protein content. The focus of this study is to evaluate if tobacco seed cake, administered in feed, can affect principal serum metabolic parameters of weaned piglets in order to establish if it can be used as both a delivery system of edible vaccines and an alternative protein source in piglets diet. A total of 48 weaned piglets were divided in two homogeneous groups for weight, control (CG) and treatment (TG); TG and CG were fed ad libitum with two isoenergetic and isoproteic experimental diets (CP: $17.68 \%$ CG and $17.64 \%$ TG) differentiated for the inclusion of $4 \%$ of tobacco seed cake in the TG diet in replacement of wheat bran and soybean meal. Growth performances were evaluated and feed intake was measured weekly. Blood samples were collected on days 0,20 and 43 to evaluate hematocrit and principal metabolic parameters, in order to assess the health status of the animals. The administration of tobacco did not impaire health status and growth performance of piglets. The use of bioenergy co-products from non-food crops may represent a good approach creating an integration between biofuel and food production, with consequent benefits for food security and environmental impact.
\end{abstract}

Keywords: Biofuel; Oilseed Cakes; Tobacco Seed; Metabolic Profiling; Protein Source; Piglets

\section{Introduction}

The most common uses of tobacco are for cigarettes, nevertheless tobacco is covering important roles in other sectors. Tobacco plays an important role in the advancement of plant biotechnology, it has been found to be an extremely versatile system for genetic manipulation and tissue culture research [1]. Several recombinant proteins are being expressed in transgenic tobacco as bioreactors for the production of commercially important pharmaceutical molecules. In particular, many immunogenic proteins have been synthesized in tobacco and several plant-based vaccine candidates have demonstrated efficacy against a large number of human and animal pathogens after oral administration [2]. Oral vaccination, through plant-derived immunogens, presents many potential advantages related to the management of intensive livestock, if compared with traditional vaccination way.

Nevertheless, antigenic proteins expressed in tobacco require the adoption of an accurate purification process, that represent the biggest cost of recombinant proteins production, because of the presence of nicotine in leaves, that is about $200 \mathrm{mg} / \mathrm{kg}$. Different studies showed the accumulation of heterologous antigenic proteins by using

${ }^{*}$ Corresponding author. suitable promoters, specifically in tobacco seeds $[3,4]$.

Tobacco seeds (Nicotiana tabacum specie) present less than $2 \mu \mathrm{g} / \mathrm{kg}$ of nicotine, and can be integrated in livestock feeding without affecting the palatability [5]. Another advantage of seeds is their ability to be stored for long periods. Recently, moreover, globally international initiatives are under way to detect renewable sources of energy $[6,7]$ and tobacco seed has been investigated as a production platform for biofuel [8].

Tobacco seed cake represent a residual product of bioenergy production with an high percentage of proteins (more concentrated after oil extraction).

Oil-seed crops, corn and sugar canes are the largest group of exploitable renewable biomass resource for liquid fuel and energy generation [9]. Crop plants oilseeds should be used in the biodiesel market only limitedly due to their value in human food chain [10]. Considering actual raw material costs and consequent food crisis, the oil demand and the need for alternative fuel oil should be filled through the use of non-edible plants [11], with a consequent strong growth of the associated co-products.

Tobacco seeds are a good source of vegetable oil which can be combusted for electrical energy and/or used as a biodiesel substitute (international patent PCT/IB/ 2007/053412). In particular, by cold pressing the seed it 
is possible to obtain both the oil, suitable for gasification and combustion, and the seed cake, a residual by-product useful in livestock as a protein source [12]. The extraction of the oil from the seed by this approach doesn't produce protein denaturation, so tobacco seed cake can be suitable used to administer vaccine proteins to the animals.

Europe is, at present, going through a crisis in proteinrich feedstuffs for livestock. The ban of animal protein sources (Decision 2000/766/EC) [13] and the increasing demand of protein-rich feeds by developing countries caused an increase of protein source costs. Soybean meal is the most commonly used plant-protein because of its technical and nutritional properties, but alternative protein sources are requested [14]. Tobacco seed cake, due to its protein content, may represent an interesting alternative to traditional feedstuffs. It has been licensed for feed use (EU feed material register, 00752-EN, 16/10/ 2010) but complete in vivo studies are still lacking.

The focus of this study is to evaluate if tobacco seed cake, administered in feed, can affect principal health parameters of weaned piglets in order to establish if it can be used as both a delivery system of edible vaccines and an alternative protein source.

\section{Material and Methods}

\subsection{Animals and Experimental Design}

The experiment was carried out in a typical intensive swine farm. Forty-eight healthy commercial hybrids piglets (Landrace $\times$ Large White from pluriparous sows) were randomly divided in eight, $2 \times 1.5 \mathrm{~m}$ square pens, with fully plastic slatted floor elevated $0.40 \mathrm{~m}$ from the ground, equipped with a nipple water and a four-hole self-feeder. In each pen animals were homogeneous for weight. Piglets, weaned at $24( \pm 2)$ days of age, were homogeneous for date of birth and free from diseases included in the A-list of the International Office of Epizootics, and also from Aujeszky's disease, atrophic rhinitis, transmissible gastroenteritis, porcine reproductive and respiratory syndrome and salmonellosis. Piglets were maintained under the same environmental conditions: temperature was initially regulated at $28^{\circ} \mathrm{C}$ and reduced of $1^{\circ} \mathrm{C}$ each subsequent post-weaning week, relative humidity has been always maintained at $60 \%$.

Animals, identified by auricular individual ID number, were divided into two groups control (CG) and treatment (TG), each of one included 24 piglets allotted in 4 pens. During 7 days after weaning, animals were fed ad libitum a pre-starter diet, formulated to cover nutritional requirement for this specific growth phase, in order to meet the NCR [15] nutrient requirements.

Fresh water was available throughout the experiment. After this adaptation period, TG and CG were fed ad libitum with two isoenergetic and isoproteic experimental diets different for the inclusion of $4 \%$ of tobacco seed cake in total replacement of wheat bran and in partial replacement of soybean meal. The ingredients and chemical composition of the diets are reported in Table $\mathbf{1}$.

Table 1. Ingredients and chemical composition of the experimental diets control (CG) and treatment (TG).

\begin{tabular}{|c|c|c|}
\hline Ingredients & CG & TG \\
\hline Corn steam flaked & 22.00 & 24.30 \\
\hline Wheat steam flaked & 17.50 & 17.50 \\
\hline Barley grain ground & 10.20 & 11.90 \\
\hline Corn grain ground & 10.00 & 10.00 \\
\hline Soybean meal $50 \mathrm{CP}$ & 9.50 & 7.30 \\
\hline Wheat bran & 5.60 & - \\
\hline Wheat middling & 5.00 & 5.00 \\
\hline Soy protein concentrate & 4.10 & 4.10 \\
\hline Sweet whey & 4.00 & 4.00 \\
\hline Sugar dextrose & 2.00 & 2.00 \\
\hline Fish meal & 3.00 & 3.00 \\
\hline Lard & 2.00 & 1.70 \\
\hline Soy oil & 1.00 & 1.00 \\
\hline Calcium carbonate & 0.95 & 0.97 \\
\hline Dicalcium phosphate & 0.85 & 0.82 \\
\hline Pea fiber & 0.60 & 0.60 \\
\hline Organic acids & 0.50 & 0.50 \\
\hline L-lysine $\mathrm{HCl}$ & 0.46 & 0.54 \\
\hline Trace elements/vitamins premix ${ }^{*}$ & 0.25 & 0.25 \\
\hline $\mathrm{NaCl}$ & 0.20 & 0.20 \\
\hline DL Methionine & 0.15 & 0.15 \\
\hline L-Threonine & 0.09 & 0.12 \\
\hline Flavor & 0.05 & 0.05 \\
\hline Tobacco seed cake & - & 4.00 \\
\hline \multicolumn{3}{|c|}{ CHEMICAL COMPOSITION ( $\%$ as feed) } \\
\hline Dry matter $(\%)$ & 88.89 & 89.09 \\
\hline Proteins, $(\%)$ & 17.68 & 17.64 \\
\hline Fats, $(\%)$ & 5.43 & 5.46 \\
\hline Crude Fiber, (\%) & 3.67 & 3.93 \\
\hline Ash, $(\%)$ & 5.35 & 5.32 \\
\hline EN swine (Mcal/kg) & 2.49 & 2.50 \\
\hline Lysine, (\%) & 1.33 & 1.34 \\
\hline Methionine, (\%) & 0.44 & 0.44 \\
\hline Methionine + Cysteine, $(\%)$ & 0.75 & 0.75 \\
\hline Threonine, $(\%)$ & 0.74 & 0.74 \\
\hline Tryptophan, (\%) & 0.20 & 0.20 \\
\hline Starch, $(\%)$ & 37.68 & 37.95 \\
\hline Lactose, $(\%)$ & 3.03 & 3.03 \\
\hline Gelatinized starch, (\%) & 15.48 & 16.36 \\
\hline Calcium, $(\%)$ & 0.97 & 0.97 \\
\hline Phosphorus, (\%) & 0.62 & 0.62 \\
\hline
\end{tabular}

${ }^{*}$ Trace elements and vitamins premix; content/kg: $25.70 \mathrm{~g} \mathrm{ZnO} ; 16.00 \mathrm{~g}$ $\mathrm{CuSO}_{4} ; 11.70 \mathrm{~g} \mathrm{MnO} ; 50.00 \mathrm{~g} \mathrm{FeCO}_{3} ; 0.32 \mathrm{Ca}\left(\mathrm{IO}_{3}\right)_{2} ; 1.905 \mathrm{~g} \mathrm{CuSO}_{4} ; 6.00 \mathrm{~g}$ $\mathrm{Na}_{2} \mathrm{SeO}_{4}$ premix $(1 \% \mathrm{Se}) ; 0.72 \mathrm{~g} \mathrm{~A} ; 600,000 / 120,000 \mathrm{IU}$ vitamin $\mathrm{A} / \mathrm{D}_{3}$; $0.012 \mathrm{~g}$ vitamin $\mathrm{D}_{3} ; 5.37 \mathrm{~g}$ vitamin $\mathrm{E} ; 1.76 \mathrm{~g}$ vitamin $\mathrm{K}_{3}$ (menadione); $0.40 \mathrm{~g}$ vitamin $\mathrm{B}_{1} ; 2.50 \mathrm{~g}$ vitamin $\mathrm{B}_{2} ; 6.00 \mathrm{~g}$ niacin; $3.00 \mathrm{~g}$ pantothenate; $2.00 \mathrm{~g}$ vitamin $\mathrm{B}_{6} ; 2.00 \mathrm{~g}$ biotine; $0.40 \mathrm{~g}$ folic acid; $10.00 \mathrm{~g}$ vitamin $\mathrm{B}_{12} ; 20.00 \mathrm{~g}$ vitamin $\mathrm{C} ; 266.67 \mathrm{~g}$ choline chloride. 
Piglets were fed the experimental diets for 43 day in order to simulate the protocol of oral administration of edible vaccines (able to enhance immunological memory).

Tobacco seed cake, obtained from Burlay wild type seeds by cold pressing according to international patent $\mathrm{PCT} / \mathrm{IB} / 2007 / 053412$, was analyzed for the main nutrient components (ether extract, crude proteins, fats, crude fiber, ash, nitrogenfree extract) according to AOAC "Official methods of analysis" in double and also for aminoacids and fatty acids composition by chromatographic according to methods previously described by Mukhtar et al. 2007 [16].

Piglets were individually weighed at days 0,20 and 43 and feed intake was measured weekly per pen. Each day piglets were individually examined by veterinarian staff, health status and clinical symptoms were recorded. At days 0 , corresponding to the beginning of treatment, 20 and 43 blood samples were collected by jugular vein using sterile needles (19 Gauge, $25 \mathrm{~mm}$ ) and $10 \mathrm{~mL}$ evacuated tubes in double. Serum samples, in 10-mL Heparinizes tubes, were separated by centrifugation and were evaluated for metabolic parameters: total proteins, albumins, globulin, albumins/globulins ratio, urea, GPT, GOT, ALP, cholesterol, calcium, phosphorus, magnesium, glucose and bilirubin by auto-analyzer. Samples, in $10-\mathrm{mL}$ EDTA tubes, were evaluated for hematocrit percentage with microcapillaries after centrifugation $12,000 \mathrm{~g} 15$ $\min$.

\subsection{Statistical Analysis}

The individual piglet was considered to be the experimental unit for the study of metabolic parameter values, while pens were the experimental units for the analysis of body weight progress and average daily gain of piglets, so different models were used for the study of metabolic traits and growth performances. Treatment effects on all considered metabolic parameters were analyzed by a multivariate repeated measures ANOVA using PROC GLM of the SAS System (Version 9.2; SAS Institute, Inc., Cary, NC). Body Weight and Average Daily Gain variables were statistically compared between the two experimental groups (Treatment vs. Control) at each different stage of the experiment (d 0, d 20 and d 43) by a univariate analysis of variance using PROC MIXED of SAS, in which the treatment represented the fixed effect of the model and the initial weight $\mathrm{W} 0$ was considered as a random variable. A separate ANOVA was performed on Average Daily Feed Intake (ADFI) per piglet at d 43 estimated on account of total feed intake per pen, using PROC MIXED of SAS and again with treatment as fixed effect and initial weight $\mathrm{W} \_0$ as random variable of the model.

\section{Results}

The analytical composition of tobacco seed cake is reported in Table 2, confirming the high level of crude proteins, that was $33.05 \%$ as feed.

Aminoacid profile showed a lysine content of $0.72 \%$ as feed and a methionine content of $0.45 \%$. Crude fat content was $9.40 \%$ and the most represented fatty acid was linoleic acid (76.59\% of total fatty acids) (Table 3).

Table 2. Chemical composition of Tobacco seed cake, as feed basis.

\begin{tabular}{cc}
\hline ITEMS & \\
\hline Dry matter (\%) & 90.30 \\
ME (Mcal/kg) & 3.17 \\
Crude protein (\%) & 33.05 \\
Ether extract (\%) & 9.40 \\
Crude fiber (\%) & 19.65 \\
Ash (\%) & 5.05 \\
Nitrogenfree extractives (\%) & 23.15 \\
\hline
\end{tabular}

Table 3. Aminoacidic and fatty acid composition of tobacco seed cake.

\begin{tabular}{ll}
\hline AMINOACIDS, \% AF & \\
\hline Aspartic acid & 2.40 \\
Threonine & 1.08 \\
Serine & 1.17 \\
Glutamic acid & 5.53 \\
Proline & 0.83 \\
Glycine & 1.29 \\
Alanine & 1.18 \\
Valine & 1.27 \\
Methionine & 0.45 \\
Isoleucine & 1.13 \\
Leucine & 1.84 \\
Phenylalanine & 1.43 \\
Histidine & 0.72 \\
Lysine & 0.72 \\
Arginine & 3.30 \\
FATTY ACIDS, \% of total fatty acids \\
Palmitic acid & 8.26 \\
Palmitoleic acid & 0.11 \\
Stearic acid & 2.85 \\
Oleic acid & 11.02 \\
Linoleic acid & 76.59 \\
Linolenic acid & 0.91 \\
Arachidonic acid & 0.16 \\
Eicosenoic acid & 0.10 \\
\hline
\end{tabular}


Growing performances were not significantly affected by the inclusion of tobacco seed cake during the entire experimental period (Table 4) and the average daily feed intake (ADFI) was not affected by treatment diet. Experimental groups presented a comparable feed consumption per pen and individually. In particular, TG registered an $\mathrm{ADFI} \pm \mathrm{SE}$ corresponding to $0.87 \pm 0.05 \mathrm{Kg} /$ day and $\mathrm{CG}$ registered an ADFI \pm SE corresponding to $0.77 \pm$ $0.04 \mathrm{Kg} /$ day. Tobacco seed cake administration did not impaire also feed efficiency (expressed as kg of feed intake to gain $1 \mathrm{~kg}$ of BW), which was, respectively $46 \%$ in TG and $48 \%$ in CG.

The average percentage of hematocrit was $28.20 \%$ in TG vs and $29.30 \%$ in CG, $28.70 \%$ in TG vs $28.60 \%$ in CG respectively at day 20 and at 43 days. The administration of tobacco seed cake did not affect metabolic parameters, predictive of general health status. Results are shown in Table 5.

All values were in the range of physiological status, in except for glycaemia. In fact glucose levels, at days 0,20 and 43 , were higher than the optimal range in both groups probably because of animals were not fasted in the moment of the blood samples collection. The only difference in trend of metabolic parameters between groups was recorded for serum phosphorus content $(\mathrm{P}<$ 0.01 ). No occurrence of any symptoms of diseases was recorded throughout the entire experimental period.

\section{Discussion}

Tobacco seed cake was tested in the most critical phase because if it demonstrated suitable for piglets, it could be safely used also in the other breeding phase. Data obtained from chemical analysis allow to classify tobacco seed cake as a raw material with middle-high protein content. Although tobacco seed cake has a lower crude protein level than soybean meal, but higher than other by-product sources (NRC, 1998). Considering the aminoacids profile, tobacco seed cake has higher lysine content than distillers dried grain with solubles, coconut oil cake and corn

Table 4. Effect of tobacco seed cake on growth performance of piglets for control (CG) and treatment (TG) groups. Data are reported as average values $\pm \mathrm{SE}$.

\begin{tabular}{ccc}
\hline ITEM & CG & TG \\
\hline Weight, $\mathrm{kg}$ & & \\
day 0 & $9.38 \pm 0.45$ & $10.21 \pm 0.48$ \\
day 20 & $15.77 \pm 0.72$ & $15.77 \pm 0.82$ \\
day 43 & $26.52 \pm 0.91$ & $27.23 \pm 1.04$ \\
ADG, kg/d & & \\
$0-20 \mathrm{~d}$ & $0.29 \pm 0.04$ & $0.29 \pm 0.04$ \\
$21-43 \mathrm{~d}$ & $0.47 \pm 0.03$ & $0.50 \pm 0.03$ \\
$0-43 \mathrm{~d}$ & $0.39 \pm 0.02$ & $0.40 \pm 0.02$ \\
\hline
\end{tabular}

Table 5. Effect of tobacco seed cake on metabolic parameters. Data are expressed as mean $\pm \mathrm{SE}$ obtained during 3 sampling days in treatment (TG) and control (CG) groups. *: $\mathbf{P}<\mathbf{0 . 0 1}$.

\begin{tabular}{|c|c|c|c|}
\hline Parameters & CG & TG & SE \\
\hline \multicolumn{4}{|c|}{ Glucose $(\mathrm{mmol} / \mathrm{L})$} \\
\hline day 0 & 6.28 & 5.80 & 0.30 \\
\hline day 20 & 6.40 & 6.04 & 0.24 \\
\hline day 43 & 6.24 & 5.99 & 0.38 \\
\hline \multicolumn{4}{|c|}{ Cholesterol (mmol/L) } \\
\hline day 0 & 1.76 & 1.85 & 0.09 \\
\hline day 20 & 2.30 & 2.20 & 0.21 \\
\hline day 43 & 1.80 & 2.21 & 0.25 \\
\hline \multicolumn{4}{|c|}{ Phosphorus $(\mathrm{mmol} / \mathrm{L})^{*}$} \\
\hline day 0 & 2.89 & 2.43 & 0.14 \\
\hline day 20 & 3.19 & 2.52 & 0.08 \\
\hline day 43 & 2.57 & $2.39 \pm$ & 0.13 \\
\hline \multicolumn{4}{|c|}{ Magnesium (mmol/L) } \\
\hline day 0 & 0.97 & $0.97 \pm$ & 0.03 \\
\hline day 20 & 0.95 & 0.86 & 0.03 \\
\hline day 43 & 0.90 & 0.83 & 0.03 \\
\hline \multicolumn{4}{|c|}{ Calcium $(\mathrm{mmol} / \mathrm{L})$} \\
\hline day 0 & 2.68 & 2.70 & 0.05 \\
\hline day 20 & 2.53 & 2.63 & 0.12 \\
\hline day 43 & 2.38 & 2.35 & 0.05 \\
\hline \multicolumn{4}{|c|}{ Serum total protein $(\mathrm{g} / \mathrm{L})$} \\
\hline day 0 & 65.1 & 64.1 & 2.53 \\
\hline day 20 & 72.1 & 69.7 & 2.11 \\
\hline day 43 & 57.8 & 61.1 & 1.36 \\
\hline \multicolumn{4}{|c|}{ Albumins $(\mathrm{g} / \mathrm{L})$} \\
\hline day 0 & 28.7 & 28.4 & 1.25 \\
\hline day 20 & 34 & 32.8 & 1.18 \\
\hline day 43 & 30.6 & 29.8 & 1.09 \\
\hline \multicolumn{4}{|c|}{ Globulins (g/L) } \\
\hline day 0 & 36.4 & 35.7 & 2.93 \\
\hline day 20 & 38.1 & 36.9 & 2.36 \\
\hline day 43 & 27.2 & 31.3 & 1.76 \\
\hline \multicolumn{4}{|l|}{$\mathrm{Alb} / \mathrm{Glob}$} \\
\hline day 0 & 0.84 & 0.84 & 0.08 \\
\hline day 20 & 0.92 & 0.92 & 0.07 \\
\hline day 43 & 1.19 & 0.97 & 0.10 \\
\hline \multicolumn{4}{|c|}{ Urea $(\mathrm{mmol} / \mathrm{L})$} \\
\hline day 0 & 4.29 & 5.19 & 0.46 \\
\hline day 20 & 4.98 & 5.25 & 0.38 \\
\hline day 43 & 3.78 & 5.14 & 0.94 \\
\hline \multicolumn{4}{|l|}{ GOT (IU/L) } \\
\hline day 0 & 62.4 & 89.8 & 16.92 \\
\hline day 20 & 43.6 & 41.1 & 3.26 \\
\hline day 43 & 74.3 & 72 & 10.74 \\
\hline \multicolumn{4}{|l|}{ ALP (IU/L) } \\
\hline day 0 & 163.4 & 168.8 & 20.17 \\
\hline day 20 & 181.3 & 139.3 & 14.24 \\
\hline day 43 & 168.1 & 136.2 & 24.63 \\
\hline \multicolumn{4}{|c|}{ Bilirubin $(\mu \mathrm{mol} / \mathrm{L})$} \\
\hline day 0 & 4 & 5.3 & 0.63 \\
\hline day 20 & 3.8 & 4.8 & 0.91 \\
\hline day 43 & 3.5 & 4.3 & 0.68 \\
\hline
\end{tabular}


gluten feed. So, when tobacco seed cake is administered, it is necessary to pay attention on lysine requirement and integrate it eventually, because is well known that it is the first limiting aminoacid in swine nutrition. On the contrary, methione content is comparable to other protein sources. From the nutrition point of view, tobacco seed cake also provide an interesting amount of lipids, represented by the oil residual after the extraction, which contribute to its significant metabolizable energy content (3170 kcal $/ \mathrm{kg} \mathrm{AF}$ ). In this trial, tobacco seed cake was evaluated in the weaning phase in order to better highlight the possible adverse effects. Nevertheless, considering the elevate crude fiber content of tobacco seed cake (19.65\% AF), its use is advisable in the diet of pregnant sows due to the high fiber requirements.

Feed intake, as well as dietary composition, are important factors for the development of the digestive organs of weaned piglets [17]. In the lifespan of the pig, the weaning phase represent a critical periods both for the correct development of the gut and the growth of the young animal.

Tobacco seed cake was administered for 43 day, according to European guidelines for the evaluation of toxicity.

The inclusion of tobacco did not impaire palatability of piglets diet according to previous findings by Rossi et al. (2007). Including tobacco seed cake did not alter mineral status. Although phosphorous level is in the physiological range, treated group showed phosphorous level lower than control group.

The different trend and the lower values in phosphorous content for treated group could be derived from the differences in endogenous phytase content and activity. As reported by Weremko et al., [18], wheat bran has an extremely higher native phytase activity than the common protein feedstuffs, such as peas, soybean, rapeseed and sunflower meal. Giving that, is possible to suppose that similar differences in native phytase activity may occur also between wheat bran and tobacco seed cake, considering that tobacco and leguminous belongs to the same tassonomic class (Magnoliopsida), different from the wheat's one (Liliopsida).

Considering that parameters mainly affected by nutritional value of feed ingredients, such as serum total proteins, urea and cholesterol were not significantly different between groups, it suggests that dietary treatment did not alter metabolism and efficiency of nutrient utilization. In particular, blood urea concentration is directly related to the rate of urea synthesis, and is, therefore, a reflection of protein metabolism in animals. Blood urea concentration can be inversely related to the efficiency of $\mathrm{N}$ utilization or lean growth and its reduction is generally associated with an increase in efficiency of $\mathrm{N}$ or lysine utilization [19]. Furthermore, the absence of alteration in trends of albumins, globulins, albumins to globulins ratio, GPT, GOT and ALP indicated that the inclusion of tobacco seed cake didn't caused liver or kidney suffering.

Focusing on delivery system for edible vaccines, the similar growing performance and metabolic parameters, combined with the absence of protein denaturation during the oil extraction by cold pressing, confirm that tobacco seed cake represent an advantageous way for oral immunization by feed. Furthermore, the extraction of the oil form seed allowed an increasing in protein content, which include the vaccinal antigens. This aspect allows to administer the right dosage of antigens throughout a lower amount of raw material, a great advantage considering the low specific weight of tobacco seed and the lower ability to intake voluminous feed by the weaned piglet, which is the target of oral immunization. In fact oral immunization trough edible vaccines must be start at least at the weaning, because of the contemporarily of the decreasing of maternal immunity and the exposure to high microbial pressure.

\section{Conclusion}

Tobacco seed cake inclusion in piglets diet was able to cover nutritional requirements of weaning piglets without affecting growing performances, feed efficiency and blood parameters. Considering that, it could be used as a cost effective protein and fiber source in swine nutrition. Cold pressing doesn't impair protein quality, so, in relation to edible vaccine production, tobacco seed cake is an effective way to obtain an higher concentration of heterologous protein than in whole seed due to the oil extraction. Moreover, using bioenergy co-products from non-food crops in animal feed could create an integration between biofuel and food production, with a consequent benefit for food security and environmental impact, according to the recent UE guidelines.

\section{Acknowledgements}

The authors are grateful to Antonio Crotti e Diego De Nisi for their constant technical support both in field and in lab. Acknowledgements to Dr. Giancarlo Selmini for his contribution. Thanks to Plantechno S.r.L. for the supply of the tobacco seed cake.

\section{REFERENCES}

[1] T. R. Ganapathi, P. Suprasanna, P. S. Rao and V. A. Bapat, "Tobacco (Nicotiana tabacum L.) -A Model System for Tissue Culture Interventions and Genetic Engineering," Indian Journal of Biotechnology, Vol. 3, 2004, pp. 171-184.

[2] H. Daniell, S. J. Streatfield and K. Wycoff, "Medical Molecular Farming: Production of Antibodies, Biopharmaceuticals and Edible Vaccines in Plants," Trends Plant 
Science, Vol. 6, No. 5, 2001, pp. 219-226. doi:10.1016/S1360-1385(01)01922-7

[3] L. Rossi, S. Reggi, A. Di Giancamillo, C. Domeneghini, L. Pinotti, C. Fogher and A. Baldi, "Oral Administration of Tobacco Seeds Expressing Antigenic Proteins in Mice Balb-C: A Model of Edible Vaccines for Oedema Disease," Italian Journal of Animal Science, Vol. 2, No. 1, 2003, pp. 7-9.

[4] L. Rossi., A. Baldi, V. Dell'Orto, S. Reggi and C. Fogher, "Expression of FlgK Flagellin from Salmonella Typhimurium in Tobacco Seeds," IOSR Journal of Pharmacy, Vol. 2, No. 1, 2012, pp. 19-22.

[5] L. Rossi, G. Selmini, F. Cheli, E. Fusi and C. Fogher, "Possibile Impiego di Panello di Seme di Tabacco Nell'Alimentazione del Suinetto," Large Animal Review, Vol. 13, 2007, pp. 211-215.

[6] A. Kumar and S. Sharma, "An Evaluation of Multipurpose Oil Seed Crop for Industrial Uses (Jatropha curcas L.): A Review," Industrial Crops and Products, Vol. 28, No. 1, 2008, pp. 1-10. doi:10.1016/j.indcrop.2008.01.001

[7] C. Schell, C. Riley and G. R. Petersen, "Pathways for Development of a Biorenewables Industry," Bioresource Technology, Vol. 99, No. 12, 2008, pp. 5160-5164. doi:10.1016/j.biortech.2007.09.085

[8] V. Andrianov, N. Borisjuk, N. Pogrebnyak, A. Brinker, J. Dixon, S. Spitsin, J. Flynn, P. Matyszczuk, K. Andryszak, M. Laurelli, M. Golovkin and H. Koprowski, "Tobacco as a Production Platform for Biofuel: Overexpression of Arabidopsis DGAT and LEC2 Genes Increases Accumulation and Shifts the Composition of Lipids in Green Biomass," Plant Biotechnology Journal, Vol. 8, No. 3, 2010, pp. 277-287. doi:10.1111/j.1467-7652.2009.00458.x

[9] E. Crabbe, C. Nolasco-Hipolito, G. Kobayashi, K. Sonomoto and A. Ishizaki, "Biodiesel Production from Crude Palm Oil and Evaluation of Butanol Extraction and Fuel Properties," Process Biochemistry, Vol. 37, No. 1, 2001, pp. 65-71. doi:10.1016/S0032-9592(01)00178-9

[10] D. Pimentel and T. W. Patzek, "Ethanol Production Using Corn, Switchgrass, and Wood; Biodiesel Production Using Soybean and Sunflower," Natural Resources Research, Vol. 14, No. 1, 2005, pp. 65-76. doi:10.1007/s11053-005-4679-8

[11] V. Balan, C. A. Rogers, S. P. S. Chundawat, L. da Costa
Sousa, P. J. Slininger, R. Gupta and B. E. Dale, "Conversion of Extracted Oil Cake Fibers into Bioethanol Including DDGS, Canola, Sunflower, Sesame, Soy, and Peanut for Integrated Biodiesel," Processing Journal of the American Oil Chemists' Society, Vol. 86, No. 2, 2009, pp. 157-165.

[12] F. Taheripour, T. W. Hertel, W. E. Tyner, J. F. Beckman and D. K. Birur, "Biofuels and Their By-Products: Global Economic and Environmental Implications," Biomass and Bioenergy, Vol. 34, No. 3, 2010, pp. 278-289. doi:10.1016/i.biombioe.2009.10.017

[13] Council Decision of 4 December 2000, "Concerning Certain Protection Measures with Regard to Transmissible Spongiform Encephalopathies and the Feeding of Animal Protein," Official Journal of the European Communities, Vol. 306, 2000, p. 32.

[14] G. Brookes, "EU Protein Ingredients: Implications of the MBM Ban," Feed International, Vol. 22, No. 4, 2001, pp. 6-11.

[15] NRC, "Nutrient Requirements of Swine," 10th Edition, National Academic Press, Washington DC, 1998.

[16] A. Mukhtar, H. Ullah and H. Mukhtar, "Fatty Acid Composition of Tobacco Seed Oil and Synthesis of Alkid Resin," Chinese Journal of Chemistry, Vol. 25, No. 5, 2007, pp. 705-708. doi:10.1002/cjoc.200790132

[17] C. A. Makkink, G. P. Negulescu, Q. Guixin and M. W. A. Verstegen, "Effect of Dietary Protein Source on Feed Intake, Growth, Pancreatic Enzyme Activities and Jejunal Morphology in Newly-Weaned Piglets," British Journal of Nutrition, Vol. 72, No. 3, 1994, pp. 353-368. doi:10.1079/BJN19940039

[18] D. Weremko, H. Fandrejewski, T. Zebrowska, K. Han, J. H. Kim and W. T. Cho, "Bioavailability of Phosphorus in Feeds of Plant Origin for Pigs," Review. Asian-Australasian Journal of Animal Sciences, Vol. 10, 1997, pp. 551566.

[19] J. Fabian, L. I. Chiba, D. L. Kuhlers, L. T. Frobish, K. Nadarajah and W. H. McElhenney, "Growth Performance, Dry Matter and Nitrogen Digestibilities, Serum Profile, and Carcass and Meat Quality of Pigs with Distinct Genotypes," Journal of Animal Science, Vol. 81, No. 5, 2003, pp. 1142-1149. 